KINGA RAŚ

Polski Instytut Spraw Międzynarodowych

\title{
Wizerunek północnego wymiaru współpracy w regionie Morza Bałtyckiego
}

\section{An image of the northern dimension of the cooperation in the Baltic Sea Region}

The aim of the article is to analyze the cooperation in the Baltic Sea Region and to assess its potential from the perspective of Poland. The hypothesis assumes that the development of cooperation in the region contributes to the deepening of integration, but it does not reduce in the expected pace the still visible disparity between countries.

As a result, Poland is still in the group of those with comparatively (relatively) weaker economic conditions and with unused potential. At the same time, acquiring experience in this dimension of cooperation, Poland not only notices the resulting benefits and opportunities, but also intensifies activities in the area of the northern dimension of the state's foreign policy.

To investigate the thesis the characteristics and analysis of integration activities in the Baltic macro-region have been made, with particular emphasis on the EU dimension (such as the EU Strategy for the Baltic Sea, EUSBSR) and the other regional cooperation formats, mainly in the framework of the Council of the Baltic Sea States (CBSS). Then, the potential of the region and Poland's involvement in cooperation in the Baltic Sea basin was evaluated. Finally, it allowed to show whether and how and how effectively Poland defines its interests in this region.

Keywords: Baltic Sea Region, Council of the Baltic Sea States (CBSS), EU Strategy for the Baltic Sea (EUSBSR), regional cooperation in the Baltic Sea Region

Słowa kluczowe: region Morza Bałtyckiego, Rada Państw Morza Bałtyckiego (RPMB), Strategia UE dla regionu Morza Bałtyckiego (SUE RMB), współpraca w regionie Morza Bałtyckiego

\section{Wprowadzenie}

Celem artykułu jest analiza współpracy w regionie Morza Bałtyckiego i ocena jego potencjału z perspektywy Polski. Hipoteza zakłada, że intensyfikacja działań i zacieśnienie kooperacji w basenie Morza Bałtyckiego przyczyniają się do pogłębienia integracji, ale nie niwelują dysproporcji między państwami 
w oczekiwanym tempie i stopniu. Polska nadal więc znajduje się w grupie tych o względnie słabszej kondycji gospodarczej i niewykorzystanym potencjale. Jednocześnie, nabywając doświadczenia w tym wymiarze współpracy, Warszawa dostrzega wynikające z tego korzyści i możliwości, dlatego zwiększa aktywność polityki zagranicznej wobec Północy.

W celu zbadania postawionej tezy dokonana zostanie próba charakterystyki i analizy przedsięwzięć prointegracyjnych w makroregionie bałtyckim, ze szczególnym uwzględnieniem wymiaru unijnego (np. Strategii UE dla regionu Morza Bałtyckiego - SUE RMB) oraz regionalnych formatów współpracy, w tym przede wszystkim Rady Państw Morza Bałtyckiego (RPMB). Następnie dokonana zostanie ocena potencjału regionu i zaangażowania Polski we współpracę w basenie Morza Bałtyckiego. Pozwoli to wykazać, czy i w jaki sposób oraz na ile efektywnie Polska definiuje i realizuje swoje interesy w wymiarze północnym polityki zagranicznej.

\section{Kształtowanie się współpracy w basenie Morza Baltyckiego}

Region Morza Bałtyckiego w wąskim znaczeniu definiowany jest w literaturze jako obszar obejmujący państwa skandynawskie ${ }^{1}$ oraz Finlandię, następnie trzy republiki bałtyckie, Polskę i Niemcy (przede wszystkim ich północne tereny: województwa zachodniopomorskie, pomorskie i warmińsko-mazurskie oraz landy Szlezwik-Holsztyn i Meklemburgia-Pomorze Przednie) i w końcu Rosję (obwody kaliningradzki i leningradzki) ${ }^{2}$. W szerszym rozumieniu zalicza się do niego Islandię, a w ramach poszczególnych inicjatyw także terytoria zależne państw nordyckich. Ponadto w ostatnich latach nad Morzem Bałtyckim zauważalnie wzrosła aktywność Wielkiej Brytanii. Choć geograficznie nie należy ona do badanego obszaru, to jednak angażuje się w regio-

1 M.J. Filipek, Struktura organizacyjna oraz główne kierunki działalności Nordyckiej Rady Ministrów, „Zeszyty Prawnicze” (UKSW) 2009, vol. 9, nr 2, s. 110-111, dostępny także w internecie [dostęp: 14.10.2018]: <http://bazhum.muzhp.pl/media//files/Zeszyty_ Prawnicze/Zeszyty_Prawnicze-r2009-t9-n2/Zeszyty_Prawnicze-r2009-t9-n2-s109-119/ Zeszyty_Prawnicze-r2009-t9-n2-s109-119.pdf>. Zob. także: B. Piotrowski, Integracja Skandynawii. Od Rady Nordyckiej do wspólnoty europejskiej, Poznań 2006; R. Matera, Integracja ekonomiczna krajów nordyckich, Torun 2001.

2 M. Grzybowski, Region Morza Battyckiego jako obszar integracji makroregionalnej w Unii Europejskiej, [w:] Perspektywy integracji gospodarczej $i$ walutowej w Unii Europejskiej w czasach kryzysu, red. K. Opolski, J. Górski, Warszawa 2013, s. 27-41, dostępny także w internecie [dostęp: 14.10.2018]: <https://mfa.gov.pl/resource/efff7d4c-826e-4208-a4cd-941f882da938:JCR>. Zob. też A. Zygierewicz, Wspótpraca państw nordyckich [Informacja nr 1115], „Biuro Studiów i Ekspertyz Kancelarii Sejmu” [online], styczeń 2005 [dostęp: 14.10.2018], dostępny w internecie: <http://biurose.sejm.gov.pl/ teksty_pdf_05/i-1115.pdf>. 
nalną kooperację, obecnie także coraz intensywniej w zakresie bezpieczeństwa. Przewiduje się, że zainteresowanie Londynu tym kierunkiem będzie wzrastać, m.in. w związku ze skutkami brexitu ${ }^{3}$.

Zakres i skala współpracy w regionie Morza Bałtyckiego mają charakter dynamiczny, a determinują je uwarunkowania geopolityczne, np. rozpad bloku państw komunistycznych, rozszerzenie UE, kryzys finansowy w strefie euro, w końcu agresywna polityka Rosji wobec Ukrainy. Głównym czynnikiem integrującym i mobilizującym państwa do współdziałania jest jednak położenie geograficzne. Istotne są tu szczególnie związki historyczne, głównie hanzeatyckich miast bałtyckich. Tradycją stała się również kooperacja państw nordyckich, które na przestrzeni lat powołały w tym celu liczne instytucje i organizacje regionalne, z kluczową rolą Rady Nordyckiej i Nordyckiej Rady Ministrów ${ }^{4}$.

Silny wpływ na zacieśnienie współpracy w regionie miały transformacja państw byłego Związku Radzieckiego oraz postępująca demokratyzacja Europy Środkowej i Wschodniej. Rozpad ZSRR zmienił również architekturę bezpieczeństwa w basenie Morza Bałtyckiego, co wpłynęło na zwiększenie zainteresowania kooperacją ze strony państw po południowo-wschodniej stronie akwenu - Polski i trzech krajów bałtyckich: Litwy, Łotwy oraz Estonii. Inauguracja współpracy nastąpiła już w 1990 r., na konferencji w szwedzkim Ronneby. Jej efektem było opracowanie w 1992 r. Wspólnego Programu Bałtyckiego, który koncentrował się głównie na kwestiach ekologii, a adresowany był właśnie do państw byłego bloku sowieckiego5. To w latach

3 Think Nordic \& Baltic. Business opportunities on your doorstep, „GOV.UK” [online], 2013 [dostęp: 14.10.2018], dostępny w internecie: <https://assets.publishing.service.gov. uk/government/uploads/system/uploads/attachment_data/file/203627/Nordic_and_Baltics_Business_Opportunity.pdf $>$. Zob. także E. Godbold, Strengthening the UK' $\bar{s}$ military power in the Baltics, „International Centre for Defence and Security” [online], sierpień 2016 [dostęp: 14.10.2018], s. 4-6 i n, dostępny w internecie: <https://icds.ee/ strengthening-the-uks-military-power-in-the-baltics/>.

4 A. Zygierewicz, Wspótpraca...; A. Moraczewska, Region Morza Battyckiego, [w:] Regiony w stosunkach międzynarodowych, red. J. Topolski, Lublin 2009, s. 65. Zob. M. Lemaitre, EU supporting cooperation across borders in the Baltic Sea Region, „Baltic Rim Economies" 2018, nr 2, s. 25.

5 I. Śmigerska-Balczak, Wspótpraca państw w regionie Morza Battyckiego - Rada Państw Morza Battyckiego, „Kwartalnik Kolegium Ekonomiczno-Społecznego »Studia i Prace «” 2012, nr 1, s. 175-198, dostępny także w internecie [dostęp: 14.10.2018]: <http://kolegia.sgh.waw.pl/pl/KES/czasopisma/kwartalnik/archiwum/Documents/ISmigerska-Belczak9.pdf>; A. Frączek, Wybrane aspekty instytucjonalizacji stosunków polsko-szwedzkich, „Studia Gdańskie. Wizje i Rzeczywistość” 2014, t. 11, s. 11, 183-195, dostępne także w internecie [dostęp: 14.10.2018]: <http://bazhum.muzhp.pl/media//files/Studia Gdanskie_Wizje_i_rzeczywistosc/Studia_Gdanskie_Wizje_i_rzeczywistosc-r2014-t11/ Studia_Gdanskie_Wizje_i_rzeczywistosc-r2014-t11-s183-195/Studia_Gdanskie_Wizjei_rzeczywistosc-r2014-t11-s183-195.pdf>. 
dziewięćdziesiątych kształtował się zakres przedmiotowy współpracy, wytyczane były kierunki współdziałania $\mathrm{w}$ regionie oraz zasadnicze cele. Dominującą rolę odgrywały w tym zakresie państwa nordyckie, które w dużym stopniu odpowiadały za definiowanie priorytetów i jednocześnie realnie planowały przyszłe działania. Główną sferą współpracy stały się wobec tego ekologia i aktywność na rzecz ochrony środowiska, określone jako najważniejsze wyzwania w regionie ${ }^{6}$.

Znaczącym krokiem w kierunku zacieśnienia współpracy bałtyckiej była Inicjatywa Regionu Morza Bałtyckiego (Inicjatywa Bałtycka) z 1996 r. ${ }^{7}$ Skierowana została przede wszystkim do państw Europy Środkowej i Wschodniej, które wspólnie z UE miały realizować projekty o charakterze infrastrukturalnym, integracyjnym oraz społecznym. Następnie stopniowo rozszerzano pakiet działań, m.in. o sektor energetyczny, czego przejawem była dyskusja na temat integracji systemów energetycznych państw regionu, do której doszło na konferencji w Gdańsku w 1998 r. Istotną rolę odegrał w tym wymiarze dokument „Bałtyk 21"8, przyjęty jeszcze w tym samym roku na szczycie Rady Państw Morza Bałtyckiego. Na tym etapie głównym celem było osiągnięcie zrównoważonego rozwoju, ale dotychczasowy zakres współpracy został rozszerzony. Ideą kooperacji było działanie na rzecz zwiększenia wykorzystania odnawialnych źródeł energii oraz ograniczenia emisji gazów do atmosfery9.

Wsparciem dla współpracy w regionie był Wymiar Północny (WP) Unii Europejskiej - skierowana bezpośrednio do regionu Morza Bałtyckiego inicjatywa, z którą w drugiej połowie lat dziewięćdziesiątych wystąpiła Finlandia ${ }^{10}$. Jej celem był rozwój dialogu i współpracy, w tym zwłaszcza wspomaganie integracji ekonomicznej oraz konkurencyjności w regionie. W porównaniu do pozostałych inicjatyw unijnych WP wyraźnie potwierdził tendencję

6 Agenda 21 dla regionu Morza Bałtyckiego, Kraków 1999 (Bałtyk 21, 1/98), dostępny także w internecie [dostęp: 14.10.2018]: <http://ofop.eu/biblioteka/14802/agenda-21-dla-regionu-morza-baltyckiego $>$.

7 S. Łodziński, Wspótpraca regionalna i transgraniczna $w$ regionie Morza Bałtyckiego [Informacja nr 660], „Biuro Studiów i Ekspertyz Kancelarii Sejmu” [online], 1999 [dostęp: 14.10.2018], dostępny w internecie: $<$ http://biurose.sejm.gov.pl/info/index.htm>.

8 Agenda $21 \ldots$

9 S. Łodziński, Wspólpraca... Przyjęta w 1996 r. bałtycka Agenda 21 zakłada trwały i zrównoważony rozwój całego regionu. Dotyczy głównie rolnictwa, energetyki, rybołówstwa, leśnictwa, przemysłu, transportu i turystyki.

10 T. Palmowski, ,Wymiar Pótnocny” Unii Europejskiej, „Stosunki Międzynarodowe” 2004, t. 29, nr 1-2, s. 26-27. 
rozszerzania ram współpracy. Dla Polski, która uczestniczy obecnie w pracach trzech spośród czterech partnerstw Wymiaru Północnego (w dziedzinie transportu i logistyki, zdrowia publicznego i opieki społecznej oraz kultury), okazał się on przydatnym narzędziem realizowania polityki na kierunku północnym.

Celem politycznym WP było przygotowanie UE i regionu bałtyckiego do kolejnego rozszerzenia Wspólnoty. Po akcesji Polski oraz państw bałtyckich głównym wyzwaniem okazała się współpraca z Rosją, zwłaszcza obwodami nadbałtyckimi ${ }^{11}$. Bałtyk stał się bowiem niemalże wewnętrznym akwenem UE, a obwód kaliningradzki - rosyjską eksklawą w jej granicach. W związku z tym WP - jako inicjatywie regionalnej - nadano ważny priorytet współpracy z Kaliningradem ${ }^{12}$. Polska z kolei zaproponowała włączenie do WP zagadnienia zanieczyszczenia Morza Bałtyckiego niebezpiecznymi odpadami i niszczejącymi zbiornikami z trującymi gazami, które od drugiej wojny światowej zalegały na dnie morza, m.in. w polskiej strefie. O ile jednak WP osiągnął w UE rangę politycznej koncepcji, o tyle nie otrzymał dodatkowych źródeł finansowania ani wspomagających zarządzanie regionem organizacji czy instytucji.

\section{Zróżnicowane formy wspólpracy w regionie}

Tradycja kooperacji w regionie Morza Bałtyckiego kształtowała się przede wszystkim na gruncie historycznym, a w wyniku zmian społeczno-politycznych na przestrzeni lat owocowała rozwojem licznych instytucji i organizacji współpracy. Efekt jest taki, że z jednej strony mamy mnóstwo realnie sprzyjających kooperacji inicjatyw na zróżnicowanym poziomie, $z$ drugiej jednak specyficzna dla regionu bałtyckiego wielość formatów może być postrzegana jako bariera dla efektywności podejmowanych działań. Poniższa krótka charakterystyka wybranych, a jednocześnie istotnych z polskiej perspektywy platform potwierdza niniejsze założenie.

11 Wymiar Pótnocny, „Ministerstwo Spraw Zagranicznych” [online, dostęp: 14.10.2018], dostępny w internecie: <https://www.msz.gov.pl/pl/c/MOBILE/polityka_zagraniczna/ baltyk/wymiar_polnocny/>. Zob. także A. Mazur-Barańska, Wymiar Pótnócny Unii Europejskiej, „Sprawy Międzynarodowe” 2000, t. 53, nr 2, s. 103.

12 Tamże, s. 34. Zob. także: T. Palmowski, ,, Wymiar Pólnocny”..., s. 26-27; Political declaration on the Northern Dimension policy, „European Union. External Action” [online, dostęp: 14.10.2018], dostępny w internecie: <http://www.eeas.europa.eu/archives/docs/ north_dim/docs/nd_political_declaration_2006_en.pdf $>$. 
Od wielu lat działalność na rzecz ochrony środowiska Morza Bałtyckiego prowadzi ustanowiona jeszcze w 1974 r. Komisja Helsińska (HELCOM). W ramach konwencji helsińskiej realizowany jest Bałtycki Plan Działań (BPD), który przyjęto na spotkaniu ministerialnym HELCOM w 2007 r. ${ }^{13}$

W wymiarze politycznym istotną rolę odgrywają niezmiennie Rada Nordycka, która zrzesza pięć państw regionu i terytoria autonomiczne, jak również Rada Bałtycka, będąca platformą współpracy trzech republik bałtyckich. Formaty bałtycki oraz nordycki, wraz z pozostałymi państwami w regionie, stanowią ważną część tzw. forum NB8. W ostatnich latach jego znaczenie sukcesywnie wzrasta, jako że po agresji Rosji na Ukrainę coraz bardziej skupia się na kwestiach bezpieczeństwa. Do współpracy włączyło się Zjednoczone Królestwo, w wyniku czego powstał rozszerzony format NB8 $+{ }^{14}$, a razem z Holandią, Niemcami i Polską stworzono Grupę Północną platformę współpracy w zakresie bezpieczeństwa skupiającą ministrów obrony dwunastu państw ${ }^{15}$.

Najważniejszym forum współpracy jest jednak obejmująca wszystkie kraje regionu Rada Państw Morza Bałtyckiego (RPMB), która powstała jeszcze w latach dziewięćdziesiątych, m.in. na bazie idei zrównoważonego rozwoju wypracowanych po rozpadzie ZSRR. Celem jej działalności jest wzmacnianie bezpieczeństwa i stabilności w regionie poprzez współpracę w wielu obszarach. Państwo, które w danym momencie sprawuje przewodnictwo (tzw. prezydencję), ma prawo określania własnych priorytetów. W praktyce jednak, owszem, lobbuje ono na rzecz własnych interesów, ale jednocześnie działa w oparciu o długoterminowe cele wspólnej strategii ${ }^{16}$.

Powyższe fora mają przede wszystkim charakter polityczny, ale w regionie nie brakuje też inicjatyw skupiających inne podmioty. Przykładem jest Związek Miast Bałtyckich (Union of the Baltic Cities - UBC) zrzeszający

13 BPD zakłada osiągnięcie dobrego stanu ekologicznego Bałtyku do roku 2021. Państwa będące stronami konwencji helsińskiej, przyjmując BPD, zobowiązały się do opracowania krajowych programów jego wdrażania.

14 Jest to format współpracy regionalnej, który obejmuje Danię, Estonię, Finlandię, Islandię, Litwę, Łotwę, Norwegię i Szwecję. Zob. NB8, „Ministry of Foreign Affairs of the Republic of Lithuania" [online], 25.06.2018 [dostęp: 14.10.2018], dostępny w internecie: $<$ https://www.urm.lt/default/en/foreign-policy/lithuania-in-the-region-and-the-world/ regional-cooperation $/ \mathrm{nb} 8>$.

15 Zob. Northern group defence ministers met in The Hague, „Government Offices of Sweden” [online], 7.06.2018 [dostęp: 14.10.2018], dostępny w internecie: $<$ https://www.government.se/articles/2018/06/northern-group-defence-ministers-met-in-the-hague>.

16 About the Programme, ,Interreg Baltic Sea Region” [online], październik 2018 [dostęp: 31.10. 2018], dostępny w internecie: <https:/www.interreg-baltic.eu/about-the-programme.html>. 
ośrodki z państw regionu $\mathrm{w}$ celu rozwijania współpracy i wymiany doświadczeń. Instytucję grupującą samorządy lokalne stworzyła Konferencja Współpracy Subregionalnej Państw Morza Bałtyckiego. Forum do dialogu politycznego parlamentarzystów jest natomiast powołana w $1991 \mathrm{r}$. w Helsinkach Konferencja Parlamentarna Morza Bałtyckiego (KPMB) ${ }^{17}$. Ma ona sprzyjać zrównoważonemu rozwojowi ekologicznemu, społecznemu i ekonomicznemu ${ }^{18}$.

Z perspektywy Polski warto również wspomnieć o programie VASAB (Wizja i Strategie wokół Morza Bałtyckiego), powołanym w 1995 r. podczas Konferencji Ministrów Planowania Przestrzennego. Dokument strategiczny VASAB Long - Dlugoterminowa Perspektywa Terytorialnego Rozwoju Regionu Morza Battyckiego (VASAB LTP) z 2009 r. określił trendy rozwoju terytorialnego i przedstawił perspektywy terytorialnej spójności dla regionu do roku $2030^{19}$.

\section{Strategia makroregionalna UE}

Rezultatem rozszerzenia Unii Europejskiej było zwiększenie zainteresowania państw regionu Morza Bałtyckiego zacieśnieniem współpracy, a następnie wpisanie jej w ramy unijne. Inicjatywa stworzenia wspólnego planu działań w basenie Bałtyku zrodziła się w Parlamencie Europejskim już w 2004 r., a pięć lat później przyjęta została Strategia Unii Europejskiej dla regionu Morza Bałtyckiego (SUE RMB) - pierwsza strategia makroregionalna UE

17 KPMB inicjuje polityczne działania w regionie i nadaje im kierunek. Wspiera i wzmacnia demokratyczne instytucje w państwach uczestniczących, usprawnia dialog między rządami, parlamentami i społeczeństwem obywatelskim, wzmacnia wspólną tożsamość regionu Morza Bałtyckiego dzięki współpracy parlamentów krajowych i regionalnych. Konferencja działa pod auspicjami Rady Państw Morza Bałtyckiego jako partner Komisji Europejskiej w oparciu o ustalenia podjęte w czasie Konferencji Ministrów Spraw Zagranicznych Rady Państw Morza Bałtyckiego w Kopenhadze w 1992 r. Konferencja Parlamentarna Morza Battyckiego, „Senat Rzeczypospolitej Polskiej” [online, dostęp: 14.10.2018], dostępny w internecie: <https://www.senat.gov.pl/kontakty-miedzyparlamentarne/stale-delegacje-do-zgromadzen-miedzyparlamentarnych/ konferencja-parlamentarna-morza-baltyckiego/>.

18 10-12.09.2018 r. w Gdańsku odbyła się Konferencja Współpracy Subregionalnej Państw Morza Bałtyckiego. Tematem obrad były solidarność oraz inteligentne działania na rzecz lepszej przyszłości. Konferencja Wspótpracy Subregionalnej Państw Morza Bałtyckiego, „Instytut Morski w Gdańsku” [online], 24.09.2018 [dostęp: 14.10.2018], dostępny w internecie: <http://im.gda.pl/aktualnosci/994-konferencja-wspopracy-subregionalnej-pastw-morza-batyckiego>.

19 Zob. portal „Vision and Strategies around the Baltic Sea” [online, dostęp: 14.10.2018], dostępny w internecie: $<$ https://vasab.org/>. 
o charakterze wewnątrzunijnym ${ }^{20}$. Realizowana jest $\mathrm{w}$ ramach instrumentów finansowych UE bądź w oparciu o środki pochodzące $\mathrm{z}$ budżetów narodowych czy międzynarodowych instytucji finansowych.

Głównym rzecznikiem SUE RMB na forum UE była Szwecja i to ona przedstawiła tę inicjatywę podczas swojego przewodnictwa w Radzie UE. Ogólną zasadą, którą wprowadzała ta formuła, było angażowanie do realizacji projektów różnorodnych podmiotów na szczeblach lokalnym, państwowym oraz unijnym. W ten sposób doszło do częściowego przeniesienia problematyki współpracy regionalnej na forum UE, co poskutkowało bardziej aktywną polityką na poziomie Wspólnoty, ale też większym zaangażowaniem poszczególnych państw, w tym Polski.

Implementacja SUE RMB oparta została o wieloletni Plan działania, zawierający obszary tematyczne i działania horyzontalne. Dokument ten skupia się na trzech głównych celach: Save the Sea, Connect the Region, Increase Prosperity. Towarzyszą im cele szczegółowe i określone wskaźniki ${ }^{21}$. Co do zasady SUE RMB nie dysponuje własnymi środkami finansowymi, jednakże realizowane $\mathrm{w}$ jej ramach projekty mogły korzystać z szerokiego wachlarza unijnych funduszy ${ }^{22}$. Zarówno motywacją, jak i wyzwaniem dla współpracy $\mathrm{w}$ regionie okazało się jego duże zróżnicowanie, co zauważalne było przede wszystkim we wciąż widocznych dysproporcjach między państwami regionu - zarówno w wymiarze gospodarczym, jak i społecznym, przy czym szczególną uwagę zwraca wysoka nierównowaga w kwestiach środowiska naturalnego.

Z uwagi na obawy części państw członkowskich, że UE skoncentruje się na północnym wymiarze współpracy kosztem pozostałych regionów, wprowadzona została zasada „trzy razy nie”: brak dodatkowych i definiowanych źródeł finansowania, brak nowych instytucji oraz brak inicjatyw legislacyjnych.

20 Komunikat Komisji do Parlamentu Europejskiego, Rady, Europejskiego Komitetu Ekonomiczno-Spotecznego i Komitetu Regionów dotyczący Strategii Unii Europejskiej dla Regionu Morza Battyckiego [COM (2009) 248/3], „Komisja Europejska” [online], 10.06.2009 [dostęp: 14.10.2018], s. 4, dostępny w internecie: <https://ec.europa.eu/ regional_policy/sources/docoffic/official/communic/baltic/com_baltic_pl.pdf $>$.

21 Od czerwca 2015 r. strategia obejmuje 13 obszarów tematycznych (policy areas) i 4 działania horyzontalne (horizontal actions), w ramach których realizowanych jest kilkadziesiąt projektów flagowych (flagship projects).

22 S. Gänzle, The European Union's Strategy for the Baltic Sea Region (EUSBSR). Improving muti-level governance in Baltic Sea cooperation?, komputeropis referatu wygłoszonego podczas 8. konferencji ECPR w Trydencie (15-18.06.2016), s. 3-4, dostępny w internecie [dostęp: 14.10.2018]: <https://ecpr.eu/Filestore/PaperProposal/2b170274-a0f5-4cf7-aa45-2173e65a6ffd.pdf $>$. 
W praktyce okazało się jednak, że założenia te przyczyniły się do powstania wielu barier, które utrudniały dalszą integrację w regionie ${ }^{23}$. Potwierdził to już pierwszy przegląd strategii. Półtora roku jej funkcjonowania ujawniło wiele słabości wynikających w znacznej mierze z jej struktury, niejasnych celów oraz nieprzejrzystego sposobu zarządzania i ograniczonych możliwości finansowania czy pozyskiwania środków ${ }^{24}$. Istotne, że ewaluacji strategii dokonano podczas polskiej prezydencji w Radzie UE, co wpłynęło na zwiększenie zainteresowania regionem ze strony Polski.

Obejmująca osiem państw członkowskich SUE RMB jest nie tylko najstarszym, ale także najbardziej zaawansowanym projektem makroregionalnym Wspólnoty. Od czasu jej przyjęcia Rada Europejska zatwierdziła kolejne trzy strategie makroregionalne UE: na rzecz regionu Dunaju (2011 r.), Morza Adriatyckiego i Jońskiego (2014 r.) oraz regionu alpejskiego (2015 r.). Obecnie trwają negocjacje na temat strategii dla Karpat ${ }^{25}$. W przeciwieństwie do pierwotnej SUE RMB w obszarze bałtyckim w kolejnych strategiach makroregionalnych już na wstępie określone zostały ramy współpracy dotyczące nie tylko wspólnych wyzwań (np. kwestii środowiskowych), ale także możliwości integracji gospodarczej w regionie.

\section{Pólnoc jako kierunek polityki zagranicznej Polski}

W polskiej polityce zagranicznej perspektywa północnego kierunku rysuje się inaczej niż w przypadku pozostałych państw regionu Morza Bałtyckiego, które nie muszą budować tzw. tożsamości bałtyckiej ${ }^{26}$. Mimo że w Polsce

23 L. Puka, Przeglad Strategii UE dla regionu Morza Battyckiego - główne wyzwania, „Biuletyn” (PISM) 2011, nr 67 (816).

24 Tamże, s. 2.

25 S. Gänzle, The European Union's Strategy... Zob. także: C. Beazley, An EU Strategy for the Baltic Sea Region. Making a success of the 2004 enlargement, „Baltic Rim Economies”2007, issue 6, s. 14; Council of the European Union, Council conclusions on the review of the European Union Strategy for the Baltic Sea Region. 3125th General Affairs Council Meeting. Brusslels, 15 November 2011, „Komisja Europejska” [online, dostęp: 14.10.2018], dostępny w internecie: <https://ec.europa.eu/regional_policy/sources/cooperate/baltic/pdf/council conclusions_eusbsr_15112011.pdf >; Czym jest strategia makroregionalna UE?, „Komisja Europejska" [online], 15.12.2017 [dostęp: 14.10.2018], dostępny w internecie: <http:// ec.europa.eu/regional_policy/pl/information/publications/factsheets/2017/what-is-an-eu-macro-regional-strategy>, <http://ec.europa.eu/regional_policy/sources/cooperate/macro_ region_strategy/pdf/mrs_factsheet_pl.pdf $>$.

26 The role of Baltic identity and cooperation in political developments [wywiad Karoliiny Raudsepp z Andresem Kasekampem], „Baltic Times” [online], 21.04.2011 [dostęp: 14.10.2018], dostępny w internecie: <https://www.baltictimes.com/news/articles/28526/>. 
mieszka aż $40 \%$ z prawie stumilionowej populacji tego obszaru, to dominują w nim małe państwa, które tradycyjnie wiązały swój rozwój przede wszystkim z kooperacją w basenie Bałtyku. Tymczasem w przypadku Polski (ale też Niemiec) mamy do czynienia z inną percepcją współpracy, trudno bowiem wskazać tu na kształtowanie polityki zagranicznej w oparciu o silną tożsamość regionalną czy północną. Działania w tym wymiarze często delegowane są bądź nawet w pełni realizowane przez podmioty lokalne (na poziomie województw, samorządów i miast) ${ }^{27}$.

Wraz z zacieśnianiem kooperacji w regionie Morza Bałtyckiego północny kierunek zyskiwał na znaczeniu w polskiej polityce, co przejawiało się aktywnością państwa na forum unijnym, wynikającą m.in. z pełnionych wówczas funkcji w UE i RPMB. Działania Polski w ramach kreowania polityki północnej na poziomie państwowym nabrały wyraźnie sektorowego charakteru, ze szczególnym uwzględnieniem bezpieczeństwa i energety$\mathrm{ki}^{28}$. Jednocześnie zaczęła ona postrzegać region jako „synonim innowacyjności, odpowiedzialności, dobrego zarządzania i dyscypliny finansowej”29. Zintensyfikowana została polityka morska, definiowana w dokumentach strategicznych, w tym Polityce morskiej Rzeczypospolitej Polskiej do roku 2020 (z perspektywa do 2030 roku ${ }^{30}$ ). Powstało również Ministerstwo Gospodarki Morskiej i Żeglugi Śródlądowej ${ }^{31}$.

Szczególnie mobilizująco na działania Polski wpłynęło z pewnością przewodnictwo w Radzie UE w 2011 r., gdy KE dokonywała przeglądu

27 M. Grzybowski, Region Morza Bałtyckiego jako obszar.., s. 1-2.

28 Działania Polski w sektorze bezpieczeństwa czy energetyki omawiane są m.in. w analizach PISM publikowanych w „Roczniku Polskiej Polityki Zagranicznej”.

29 Informacja Rady Ministrów o zadaniach polskiej polityki zagranicznej w latach 2014-2015, „Ministerstwo Spraw Zagranicznych” [online], 6.11.2014 [dostęp: 14.10.2018], dostępna w internecie: <http://www.msz.gov.pl/pl/aktualnosci/wiadomosci/minister_grzegorz_ schetyna_o_priorytetach_polskiej_dyplomacji>. Zob. także: Informacja Ministra Spraw Zagranicznych nt. polityki zagranicznej RP w 2011 r., „Ministerstwo Spraw Zagranicznych" [online, dostęp: 14.10.2018], dostępny w internecie: <http://msz.gov.pl/pl/ polityka_zagraniczna/priorytety_polityki_zagr_2012_2016/expose2/expose2011/>.

30 Polityka morska Rzeczypospolitej Polskiej do roku 2020 (z perspektywa do 2030 roku), Warszawa 2015, [załącznik do:] Uchwała nr 33/2015 Rady Ministrów z dnia 17 marca 2015 r. w sprawie Polityki morskiej Rzeczypospolitej Polskiej do roku 2020 (z perspektywa do 2030 roku), „Ministerstwo Gospodarki Morskiej i Żeglugi Śródlądowej” [online, dostęp: 14.10.2018], dostępny w internecie: <https://mgm.gov.pl/wp-content/ uploads/2016/01/Polityka-morska-Rzeczypospolitej-Polskiej_uchw.NN_33_RM_z_17_ 03_2015.pdf $>$.

31 Exposé premier Beaty Szydto - stenogram, „Premier” [online], 15.11.2015 [dostęp: 14.10.2018], dostępne w internecie: <https://www.premier.gov.pl/expose-premier-beaty-szydlo-stenogram.html>. 
SUE RMB. Motywowało to do zwiększenia zaangażowania kraju na rzecz polityki północnej, i to nie tylko na poziomie lokalnym. Proces rewizji Planu działania oraz dopasowywania SUE RMB do aktualnych wyzwań wiązał się z intensywnymi, blisko rocznymi pracami Polski nad oceną funkcjonowania strategii. Zapisy wskazujące na konieczność dokonania przeglądu SUE RMB podczas polskiej prezydencji znalazły się w raporcie KE na temat jej wdrażania ${ }^{32}$.

W kolejnych latach Polska rozwijała politykę regionalną w basenie Morza Bałtyckiego, dostrzegając potencjał tego kierunku, wynikający m.in. z wyróżniającej region stabilności politycznej i gospodarczej ${ }^{33}$. Przewodnictwo w RPMB w latach 2015-2016 jeszcze bardziej zmobilizowało Warszawę do zaangażowania na rzecz realizacji SUE RMB. Wymagało to wzmożonych działań na poziomie dyplomatycznym (m.in. większego zaangażowania kadrowego, i to nie tylko Ministerstwa Spraw Zagranicznych), ale było również okazją do bardziej aktywnego uczestnictwa na forum, w tym forsowania własnego stanowiska, np. w sprawie relacji z Rosją czy definiowania priorytetów Rady.

W ostatnich latach decydującym czynnikiem warunkującym działania Polski i pozostałych państw Morza Bałtyckiego było bezpieczeństwo. Do zacieśnienia współpracy w tym obszarze determinowały rosyjska agresja na Ukrainę i konsekwentnie wzmagająca się aktywność tego państwa w basenie Bałtyku (o czym świadczy rosnąca liczba incydentów na wodzie i w powietrzu). Współpraca w tym wymiarze stanowiła element priorytetowy i często wykraczała poza instytucjonalne ramy regionu, czego przykładem może być zaangażowanie NATO we wzmocnienie wschodniej flanki. W konsekwencji doszło do wyraźnego ograniczenia relacji z Rosją. Czynnik bezpieczeństwa wpływał też bezpośrednio na działania RPMB, ponieważ rozpętany w 2014 r. konflikt na Ukrainie skutecznie utrudniał kooperację z Rosją, a w rezultacie realizację wyznaczonych celów, i osłabił instytucjonalną sprawność tego najważniejszego w regionie forum ${ }^{34}$.

32 Czym jest Strategia UE dla regionu Morza Battyckiego, „Ministerstwo Spraw Zagranicznych" [online, dostęp: 14.10.2018], dostępny w internecie: <https://msz.gov.pl/pl/ polityka_zagraniczna/baltyk/strategia/czym_jest_strategia/>.

33 A. Purju, The economies of the Baltic Sea Region. Growth patterns and foreign trade now and in the future, ,Journal of East-West Business” 2013, vol. 19 (1-2), s. 4-15.

34 Szerzej na temat uwarunkowań polskiej polityki w regionie Morza Bałtyckiego zob. K. Raś, Polityka Polski w regionie Morza Battyckiego, „Rocznik Polskiej Polityki Zagranicznej" 2016 [w druku]. 


\section{Przewodnictwo w Radzie Państw Morza Baltyckiego}

Od lipca 2015 do czerwca 2016 r. Polska przewodniczyła RPMB, co dawało okazję do wzmocnienia relacji bilateralnych z państwami nordyckimi i wymiany doświadczeń, a także lobbowania na rzecz tzw. południowo-wschodniego Bałtyku. Warszawa dążyła też wówczas do silniejszego akcentowania swojej obecności w regionie, by móc w większym stopniu pozycjonować się jako łącznik między regionami na osi Północ-Południe ${ }^{35}$.

Sprawując prezydencję, Polska skupiła się na trzech priorytetach: wypracowaniu nowej agendy zrównoważonego rozwoju dla regionu Morza Bałtyckiego po 2015 r., działaniach związanych z adaptacją do zmian klimatu oraz budowaniu synergii między różnymi organizacjami i grupami, które zajmują się zrównoważonym rozwojem w regionie ${ }^{36}$. Udało się wówczas przedłużyć do 2018 r. mandat Grupy Ekspertów ds. Zrównoważonego Rozwoju Baltic 2030 oraz przyjąc deklarację Baltic 2030. Renewing the commitment to sustainable development in the Baltic Sea Region ${ }^{37}$, odnawiającą i potwierdzającą szereg zobowiązań dotyczących zrównoważonego rozwoju w regionie Bahtyku ${ }^{38}$.

Polska prezydencja w RPMB zbiegła się w czasie z koordynowaniem przez Warszawę SUE RMB, co wymagało dużego zaangażowania kadrowego i organizacyjnego. Największym przedsięwzięciem w tym okresie okazała się zorganizowana we wrześniu 2015 r. sesja ministrów kultury RPMB - pierwsze

35 „Nasz kraj łączy dwa wielkie obszary europejskie - szeroko pojęty region Morza Bałtyckiego i Europę Środkową z państwami bałkańskimi po Morze Adriatyckie. Nie tylko będziemy obecni w różnych formatach współpracy w ramach poszczególnych regionów, ale będziemy również dążyć do tego, by za pośrednictwem naszego kraju północ i południe Europy były sobie bliższe”. Petna treść exposé Witolda Waszczykowskiego, „Rzeczpospolita" [online], 29.01.2016 [dostęp: 14.10.2018], dostępny w internecie: <https://www. rp.pl/Rzad-PiS/160129236-Pelna-tresc-expose-Witolda-Waszczykowskiego.html>.

36 K. Popławski, Cele polskiej prezydencji w Radzie Państw Morza Baltyckiego, „Przegląd Bałtycki" [online], 17.01.2016 [dostęp: 14.10.2018], dostępny w internecie: <http:// przegladbaltycki.pl/2265,cele-polskiej-prezydencji-w-radzie-panstw-morza-baltyckiego. html>. Por. Polska prezydencja w Radzie Państw Morza Baltyckiego, „Ministerstwo Spraw Zagranicznych" [online], 1.07.2015 [dostęp: 14.10.2018], dostępny w internecie: $<$ https:// www.msz.gov.pl/pl/p/paryz_fr_a_pl/aktualnosci/polska_prezydencja_w_radzie_panstwa morza_baltyckiego?searchTag=>.

37 Baltic 2030. Renewing the commitment to sustainable development in the Baltic Sea Region, 6.06.2016, dostępna na portalu „Council of the Baltic Sea States” [online, dostęp: 14.10.2018]: <http://www.cbss.org/wp-content/uploads/2016/06/CBSS-Declaration-Baltic-2030--Warsaw-6-of-June-20161.pdf>.

38 B. Ćwioro, Bałtyk na nowe czasy - przewodnictwo Polski w Radzie Państw Morza Bałtyckiego, 1 lipca 2015 - 30 czerwca 2016, [w:] Bałtyk dla wszystkich 2016, [b.m.w. 2016], s. 22-23. 
spotkanie szefów tych resortów od siedmiu lat ${ }^{39}$. Działania Polski na rzecz głównego priorytetu, czyli synergii w różnorodności, miały wzmocnić regionalną spójność oraz sprzyjać rozwojowi dialogu strukturalnego w ramach różnych formatów współpracy w Europie Północnej ${ }^{40}$. Wdrożono w tym celu innowacyjne rozwiązania, jak formuła synergii formatów, co miało służyć przezwyciężeniu krytykowanej słabości instytucjonalnej i organizacyjnej $\mathrm{RPMB}^{41} .9$ marca $2016 \mathrm{r}$. w Warszawie zorganizowano poświęcone tej tematyce seminarium z udziałem ekspertów od polityki i współpracy regionalnej z krajów RPMB oraz członków Komitetu Wyższych Urzędników (KWU) tej organizacji.

Warto ponadto podkreślić, że to podczas polskiego przewodnictwa odbyła się pierwsza wspólna sesja z udziałem KWU RPMB, narodowych koordynatorów SUE RMB, koordynatorów obszarów tematycznych (PAC) i działań horyzontalnych (HAC) SUE RMB oraz polskiego przewodnictwa w Partnerstwie ds. Kultury Wymiaru Północnego (NDPC). Mimo tych wysiłków w kolejnych latach państwa nie osiągnęły konsensusu co do konkretnych zmian w sposobie zarządzania Radą, co potwierdziły szwedzka i łotewska prezydencja. Kontynuowano jednak dyskusję, jak usprawnić komunikację między głównymi interesariuszami, czyli Narodowymi Koordynatorami, KE, PAC i HAC ${ }^{42}$. Zwiększenie efektywności i transparentności podejmowanych działań wymaga rozwiązania problemu krzyżowania się szeregu kompetencji i inicjatyw tych podmiotów.

W czasie polskiej prezydencji doszło też do wznowienia w ramach RPMB dialogu politycznego na wysokim szczeblu. 8 czerwca 2016 r., po trzech latach przerwy będącej konsekwencją rosyjskiej agresji na Ukrainę, odbyła

39 „Baltic Science Network” [online, dostęp: 14.10.2018], dostępny w internecie: <http:// www.baltic-science.org/>.

40 Dlatego doszło do połączenia przewodnictwa nad pracami RPMB i grupy Narodowych Koordynatorów SUE RMB.

41 Pierwsze spotkanie w formule synergii formatów odbyło się przy okazji Bałtyckiego Forum Kultury i poświęcone było kulturze jako narzędziu rozwoju ekonomiczno-społecznego w regionie Morza Bałtyckiego. 9. Spotkanie Ministrów Kultury Regionu Morza Baltyckiego, „Ministerstwo Spraw Zagranicznych” [online], 23.09.2015 [dostęp: 14.10.2018], dostępny w internecie: <https://www.msz.gov.pl/pl/polityka_zagraniczna/ baltyk/prezydencja/9_spotkanie_ministrow_kultury_regionu_morza_baltyckiego;jsessionid=335F7F666FBA0B26573B3D39458452AE.cmsap5p $>$.

42 Latvian Presidency 2018-2019, „Council of the Baltic Sea States” [online, dostęp: 14.10.2018], dostępny w internecie: $<\mathrm{http} / /$ www.cbss.org/latvian-presidency-2018-2019/>; Swedish Presidency 2017-2018, „Council of the Baltic Sea States” [online, dostęp: 14.10. 2018], dostępny w internecie: <http://www.cbss.org/swedish--presidency-2017-2018/>. 
się w Warszawie sesja wiceministrów spraw zagranicznych Rady, co było ważnym krokiem w kierunku odzyskania przez nią przywództwa politycznego w regionie. Co istotne, RPMB stanowiła jedną z nielicznych organizacji, w ramach której państwa UE i Rosja prowadziły choćby ograniczoną komunikację na poziomie współpracy organizacyjnej i projektowej. Przed kryzysem ukraińskim realizowano z nią natomiast wiele wspólnych przedsięwzięć. Odpowiadała np. za współpracę w zakresie radiacji i energii atomowej, opracowując standardy użycia izotopów na potrzeby kryminalistyki. W formacie tym intensywnie rozwijana była ponadto współpraca policji, straży pożarnej, straży granicznej oraz prokuratur.

Podczas polskiego przewodnictwa decyzją Komitetu Seniorów przedłużono mandat Grupy Ekspertów ds. Polityki Morskiej (EGMP ${ }^{43}$ ) do 2018 r. Skupiła się ona wówczas na transparentnej koordynacji polityki morskiej państw członkowskich, szczególnie w aspekcie bezpieczeństwa w regionie i promocji czystej żeglugi w basenie Morza Bałtyckiego. Zaprezentowano też $\mathrm{w}$ tym okresie szereg dokumentów strategicznych wdrażanych w ramach narodowych polityk morskich, np. uchwałę Polityka morska Rzeczypospolitej Polskiej do 2020 (z perspektywa do 2030 r.), która zakładała m.in. zwiększenie konkurencyjności transportu morskiego jako najbardziej ekologicznego ${ }^{44}$.

Działając na rzecz synergii, Polska priorytetowo potraktowała obszar kultury i wymiaru społecznego, za który odpowiadało m.in. Ministerstwo Kultury i Dziedzictwa Narodowego. Najważniejszym przedsięwzięciem w tej sferze było spotkanie ministrów kultury państw Morza Bałtyckiego zorganizowane 16 września 2015 r. w Gdańsku, w ramach Bałtyckiego Forum Kultury ${ }^{45}$.

43 EGMP nadal pozycjonuje RPMB jako cennego partnera w Bałtyckim Dialogu Morskim, w pełni uwzględniając działania w ramach strategii UE dla regionu Morza Bałtyckiego (PA Ship PA Safe) oraz Partnerstwa Wymiaru Północnego w zakresie Transportu i Logistyki. W ramach dialogu EGMP oraz HELCOM Maritime Working Group zorganizowały partnerstwa na rzecz ekologicznej żeglugi (Partnerships for Green Shipping) podczas Europejskiego Dnia Morza 2016 w Turku, którego celem było promowanie takiego transportu.

44 Grupa referencyjna ZVT składa się z przedstawicieli agencji rządowych i administracji, a także przedstawicieli branży. Dwie inne instytucje, które mają status obserwatora, to szwedzkie Ministerstwo Przedsiębiorczości, Energetyki i Komunikacji oraz szwedzkie Ministerstwo Środowiska

45 Bałtyckie Forum Kultury odbyło się we wrześniu 2015 r. z inicjatywy Ministerstwa Kultury i Dziedzictwa Narodowego. Zob. Battyckie Forum Kultury, „Ministerstwo Spraw Zagranicznych" [online], 6.09.2015 [dostęp: 14.10.2018], dostępny w internecie: <http:// www.mkidn.gov.pl/pages/posts/baltyckie-forum-kultury-5726.php>. 


\section{Potencjal regionu Morza Baltyckiego}

W obszarze spójności regionalnej, a zatem również w zakresie zrównoważonego wzrostu gospodarczego w basenie Morza Bałtyckiego, zasadniczym wyzwaniem pozostają dysproporcje między państwami. Potwierdza to poziom rozwoju mierzony wskaźnikiem PKB per capita, który dla części krajów regionu był nawet dwukrotnie wyższy niż w przypadku innych.

Tabela 1. PKB i PKB per capita $w$ regionie Morza Baltyckiego

\begin{tabular}{|c|c|c|c|}
\hline Państwo & Rok & PKB (mld USD) & PKB per capita (USD) \\
\hline \multirow{3}{*}{ DANIA } & 2005 & 264,50 & 43085 \\
\hline & 2010 & 322,00 & 58041 \\
\hline & 2016 & 306,10 & 53417 \\
\hline \multirow{3}{*}{ ESTONIA } & 2005 & 14,01 & 10338 \\
\hline & 2010 & 19,49 & 14638 \\
\hline & 2016 & 23,14 & 17524 \\
\hline \multirow{3}{*}{ FINLANDIA } & 2005 & 204,40 & 30900 \\
\hline & 2010 & 247,80 & 35400 \\
\hline & 2016 & 236,80 & 43090 \\
\hline \multirow{3}{*}{ NIEMCY } & 2005 & 2861,00 & 34696 \\
\hline & 2010 & 3417,00 & 35,785 \\
\hline & 2016 & 3467,00 & 41936 \\
\hline \multirow{3}{*}{ LOTWA } & 2005 & 16,92 & 7558 \\
\hline & 2010 & 23,76 & 11326 \\
\hline & 2016 & 27,68 & 14118 \\
\hline \multirow{3}{*}{ LITWA } & 2005 & 26,13 & 7863 \\
\hline & 2010 & 37,12 & 11984 \\
\hline & 2016 & 42,74 & 14879 \\
\hline \multirow{3}{*}{ NORWEGIA } & 2005 & 308,70 & 66775 \\
\hline & 2010 & 428,50 & 87646 \\
\hline & 2016 & 370,60 & 70812 \\
\hline \multirow{3}{*}{ POLSKA } & 2005 & 306,10 & 8021 \\
\hline & 2010 & 479,30 & 12599 \\
\hline & 2016 & 469,50 & 12347 \\
\hline \multirow{3}{*}{ ROSJA } & 2005 & 764,00 & 5323 \\
\hline & 2010 & 1525,00 & 10674 \\
\hline & 2016 & 1283,00 & 8478 \\
\hline \multirow{3}{*}{ SZWECJA } & 2005 & 389,00 & 43085 \\
\hline & 2010 & 488,40 & 52076 \\
\hline & 2016 & 511,00 & 51599 \\
\hline
\end{tabular}

Źródło: oprac. własne na podstawie danych Banku Światowego 
Mimo zaawansowanej współpracy w ramach RMB długotrwałe dysproporcje PKB per capita w tych państwach utrzymują się. Nie sposób tu jednak nie dostrzec dość istotnych zmian. O ile w 2005 r. w Estonii, Łotwie, Litwie, Polsce i Rosji wskaźnik ten wynosił średnio ok. 38\% średniego PKB per capita w Danii, Finlandii, Niemczech, Norwegii i Szwecji, to w 2015 r. wzrósł do ok. 46\% (a nawet 54\%, jeśli nie uwzględniać Rosji) ${ }^{46}$. Poprawił się jednocześnie klimat do rozwoju biznesu, co potwierdził opracowany przez Bank Światowy ease of doing business index, który porządkuje gospodarki, biorąc pod uwagę dziesięć czynników sprzyjających uruchamianiu i funkcjonowaniu lokalnych firm. W 2016 r. wyniki dla regionu Morza Bałtyckiego przedstawiały się następująco: Dania zajęła 3. miejsce (8. w 2005 r.), Estonia - 12. (16. w 2005 r.), Finlandia - 13. (to samo w 2005 r.), Niemcy - 17. (19. w 2005 r.), Litwa - 21. (15. w 2005 r.), Łotwa 14. (26. w 2005 r.), Norwegia - 6. (5. w 2005 r.), Polska - 24. (54. w 2005 r.), Rosja - 40. (79. w 2005 r.) i Szwecja - 9. (14. w 2005 r.). Średnia regionu wzrosła zatem prawie o 10 pozycji (z 25. miejsca w 2005 r. do 16. w 2016), a różnice między rankingiem poszczególnych państw z czasem się zmniejszyły ${ }^{47}$.

Statystyki potwierdziły tkwiący w regionie potencjał, co tym bardziej skłaniało do współpracy na rzecz synergii. Wskazały przy tym na wyraźnie większą zdolność inwestycyjną Skandynawii niż krajów południowo-wschodniego Bałtyku, jak Polska, republiki bałtyckie czy Rosja (głównie obwód kaliningradzki). Przekładało się to na relacje gospodarcze, w tym rosnącą rolę Polski jako partnera handlowego państw skandynawskich. Tamtejsze firmy plasowały się na szóstym miejscu wśród inwestorów zagranicznych w Polsce, a ich udział w ogólnej wartości BIZ szacowano na nieco ponad 6\%, przy czym rekordowy napływ inwestycji (3,2 mld euro) nastąpił w $2011 \mathrm{r}^{48}$ Nad Wisłą działało wtedy około 2200 firm z kapitałem skandynawskim, reprezentujących łącznie ok. 9\% kapitału zagranicznego ${ }^{49}$. Większość $\mathrm{z}$ nich działała $\mathrm{w}$ sektorach przetwórstwa przemysłowego oraz handlu. W przypadku firm duńskich silnie reprezentowanymi branżami były budownictwo i obsługa rynku nieruchomości, a spółki norweskie wyróżniały się działalnością na rynku nieruchomości oraz w branżach związanych z zakwaterowaniem i gastronomią ${ }^{50}$.

46 H. Fanning, The economic development of the Baltic Sea Region - what major indicators tell us, „Baltic Rim Economies” 2017, issue 1, s. 51.

47 Tamże, s. 51.

48 Polsko-skandynawska wspótpraca gospodarcza. Inwestycje, wymiana handlowa i skandynawscy inwestorzy w Polsce, Warszawa 2016, s. 21.

49 Tamże, s. 22-23.

50 Tamże, s. 25. 
Według danych Skandynawsko-Polskiej Izby Gospodarczej (SPCC) od ponad dziesięciu lat saldo wymiany handlowej z państwami skandynawskimi było dodatnie dla Polski. Dodatkowo od 2009 r. ciągle rosło i w 2015 wyniosło szacunkowo ponad 2,65 mld euro. Wartość wzajemnej wymiany handlowej z państwami skandynawskimi utrzymywała się na stałym poziomie ok. $20 \mathrm{mld}$ euro rocznie ${ }^{51}$. W przypadku handlu Polski z państwami bałtyckimi nominalna wielkość obrotów była co prawda wyraźnie niższa niż ze Skandynawią, jednakże z uwagi na efekt skali oraz ograniczone zasoby Litwy, Łotwy i Estonii wymiana była znacząca, gdyż Polska od lat jest jednym z ich głównych partnerów handlowych ${ }^{52}$. Dotyczy to przede wszystkim Litwy, dla której Polska była w tym czasie trzecim po Rosji i Niemczech dostawcą towarów.

Tabela 2. Polski handel zagraniczny z państwami regionu Morza Baltyckiego w latach 2015-2017 (w mld euro)

\begin{tabular}{|c|c|c|c|c|c|c|}
\hline Państwo & Rok & Import & Eksport & SALDO & Import (\%) & Eksport (\%) \\
\hline \multirow{3}{*}{ DANIA } & 2015 & 3,0 & 2,1 & 0,8 & . & . \\
\hline & 2016 & 2,1 & 3,2 & 1,1 & 1,9 & 2,2 \\
\hline & 2017 & 2,5 & 3,8 & 1,3 & 1,2 & 1,8 \\
\hline \multirow{3}{*}{ ESTONIA } & 2015 & 0,2 & 1,0 & 0,9 & $-6,0$ & 6,0 \\
\hline & 2016 & 2,2 & 1,0 & 0,8 & 0,2 & 0,7 \\
\hline & 2017 & 2,4 & 1,1 & 0,9 & 0,1 & 0,6 \\
\hline \multirow{3}{*}{ FINLANDIA } & 2015 & 1,5 & 1,4 & $-0,1$ & . & . \\
\hline & 2016 & 1,4 & 1,5 & 0,1 & 1,3 & 1,0 \\
\hline & 2017 & 2,4 & 1,6 & 0,9 & 0,8 & 0,8 \\
\hline \multirow{3}{*}{ LITWA } & 2015 & 1,0 & 2,5 & 1,5 & 9,5 & 10,5 \\
\hline & 2016 & 1,2 & 2,6 & 1,3 & 1,1 & 1,8 \\
\hline & 2017 & 1,6 & 3,0 & 1,3 & 0,8 & 1,4 \\
\hline \multirow{3}{*}{ LOTWA } & 2015 & 0,4 & 1,5 & 1,1 & $-0,5$ & $-9,5$ \\
\hline & 2016 & 0,3 & 1,3 & 1,0 & 0,3 & 0,9 \\
\hline & 2017 & 0,4 & 1,3 & 0,9 & 0,2 & 0,6 \\
\hline \multirow{3}{*}{ NORWEGIA } & 2015 & 2,3 & 2,5 & 0,6 & 4,7 & 11,5 \\
\hline & 2016 & 1,9 & 2,2 & 0,3 & 9,2 & 14,1 \\
\hline & 2017 & 2,2 & 2,4 & 0,1 & 1,1 & 1,1 \\
\hline \multirow{3}{*}{ SZWECJA } & 2015 & 5,0 & 3,2 & 1,7 & 7 & 4,5 \\
\hline & 2016 & 3,1 & 5,3 & 2,2 & 2,8 & 3,6 \\
\hline & 2017 & 4,0 & 5,9 & 1,9 & 1,9 & 2,8 \\
\hline
\end{tabular}

Źródło: oprac. własne na podstawie danych Głównego Urzędu Statystycznego

51 Tamże, s. 27.

52 K. Raś, Polityka zagraniczna Polski wobec państw battyckich, „Rocznik Polskiej Polityki Zagranicznej” 2016 [w druku]. 
Początkowo dla Polski Skandynawia była ważna przede wszystkim ze względu na duży udział inwestycji, ale z czasem okazała się też jednym z głównych kierunków eksportowych, mieszcząc się w ostatnich latach w pierwszej piątce rynków dla polskich towarów i usług ${ }^{53}$. Potencjał współpracy gospodarczej z Polską wiązał się również z dynamicznym postępem w digitalizacji przemysłu i usług, co wedle szacunków może przynieść dla przemysłu dodatkowe 110 mld euro przychodów rocznie. Według badania Cleantech Finland znaczenie Polski jako potencjalnego rynku dla czystych technologii może wzrosnąć z 18\% w 2016 r. do prawie 40\% w $2020^{54}$.

Atrakcyjność regionu Morza Bałtyckiego dla Polski rośnie też właśnie z uwagi na rozwój innowacyjności, szczególnie w państwach skandynawskich, które niezmiennie utrzymują na tym polu czołowe pozycje. W $2017 \mathrm{r}$. w obejmującym 36 państw europejskim rankingu innowacyjności (European Innovation Scoreboard ${ }^{55}$ ) Szwecja, Dania i Finlandia zajęly miejsca od pierwszego do trzeciego (ale bez uwzględnienia Szwajcarii) i znalazły się grupie liderów innowacji. Norwegia znalazła się na miejscu 17., a Polska - na 29., co lokuje ją pośród krajów umiarkowanie innowacyjnych. Trzeba przy tym wyraźnie podkreślić, że wskaźniki innowacyjności dla czołowych państw regionu były znacznie wyższe niż średnia w $\mathrm{UE}^{56}$.

Według Global Competitiveness Index na lata 2017-2018 ${ }^{57}$ państwa skandynawskie znalazły się wśród 15 najbardziej konkurencyjnych gospodarek świata: Finlandia zajęła miejsce 10., Szwecja - 7., Norwegia - 11., a Dania -12 . Niemcy uplasowały się w tym rankingu na 5. pozycji, Polskana 39., Estonia - na 29., Litwa - na 41., Łotwa - na 54., a Rosja - na 38.

Wyzwania dotyczące innowacyjności stoją zarówno przed Polską, jak i całym regionem Europy Środkowej i Wschodniej. Zagadnienia powiązane $\mathrm{z}$ tym obszarem będą więc coraz częściej miały status priorytetowy. Z raportu

53 Polsko-skandynawska wspótpraca..., s. 28.

54 Tamże.

55 Europejski Ranking Innowacyjności 2018: Europa musi zwiększyć przewagę $w$ dziedzinie innowacji, „Komisja Europejska” [online], 22.06.2018 [dostęp: 14.10.2018], dostępny w internecie: $<$ http://europa.eu/rapid/press-release_IP-18-4223_en.htm>.

56 I. Trusewicz, Skandynawia znów bije świat na głowę, ,Rzeczpospolita” [online], 25.06.2017 [dostęp: 14.10.2018], dostępny w internecie: <https://www.rp.pl/Gospodarka/306259964-Skandynawia-znow-bije-swiat-na-glowe.html>.

57 European innovation scoreboard 2018, Luxembourg 2018, dostępny w internecie [dostęp: 14.10.2018]: <https://ec.europa.eu/docsroom/documents/33147?locale=pl>; The global competitiveness report 2017-2018, ed. K. Schwab, Geneva 2017, s. 7, dostępny w internecie [dostęp: 14.10.2018]: <http://www3.weforum.org/docs/GCR2017-2018/05FullReport/TheGlobalCompetitivenessReport2017\%E2\%80\%932018.pdf>. 


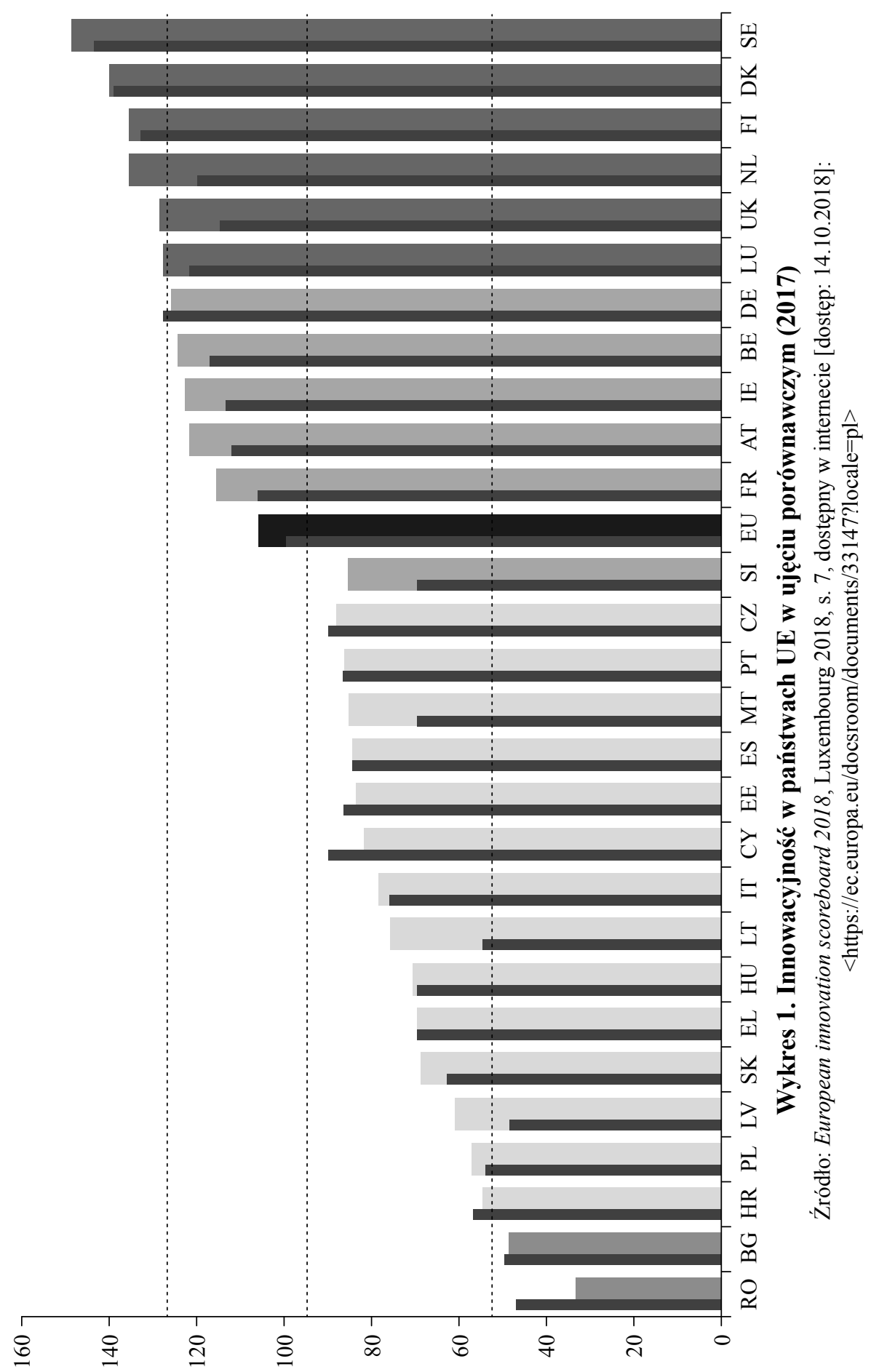


na temat innowacyjności w Polsce wynika, że już obecnie rodzime firmy muszą podejmować wiele decyzji związanych z tym obszarem. Współpracę przedsiębiorców ze start-upami ma wspierać Polski Fundusz Rozwoju, oferujący instrumenty wspomagające rozwój krajowych firm. Jednocześnie ponad połowa badanych przedsiębiorstw jako największą przeszkodę w tworzeniu innowacji wskazała problemy organizacyjne. Najwięcej, bo aż $21 \%$ z nich potwierdziło niedostosowanie własnej kultury organizacyjnej do strategii innowacji ${ }^{58}$. Know-how w tym zakresie mają natomiast przedsiębiorstwa skandynawskie, co tym bardziej czyni z tego regionu ważnego partnera dla Polski.

\section{Podsumowanie}

Na przestrzeni lat Polska wyraźnie zintensyfikowała współpracę zagraniczną w regionie Morza Bałtyckiego. Wpłynęło na to kilka czynników:

- rozwój i intensyfikacja unijnej polityki makroregionalnej;

- przewodnictwo Polski w Radzie UE, gdy dokonywano przeglądu strategii UE dla regionu Morza Bałtyckiego, i prezydencja w Radzie Państw Morza Bałtyckiego;

- potencjał stabilnego gospodarczo i wyróżniającego się możliwościami (m.in. w zakresie innowacyjności) regionu.

Rosnące zaangażowanie Polski w regionie wynikało też z chęci wzmocnienia tego kierunku w działaniach zewnętrznych i umocnienia pozycji państwa nie tylko w obszarze Morza Bałtyckiego, ale również w UE. Pozwoliło to na efektywniejsze wykorzystanie tkwiącego w tym wymiarze współpracy potencjału. Ze względu na zmianę uwarunkowań geopolitycznych, w tym zwiększoną aktywność Rosji w basenie Morza Bałtyckiego, we współpracy w ramach RMB coraz bardziej dominował czynnik bezpieczeństwa, co spowodowało spadek znaczenia pozostałych jej wymiarów. Nie zniknęły one jednak z agendy polskiej polityki zagranicznej.

58 Kierunek innowacje! Polskie firmy na ścieżce rozwoju, „PwC” [online], listopad 2017 [dostęp: 14.10.2018], s. 20 i n, dostępny w internecie: <https://www.pwc.pl/pl/pdf/publikacje/kierunek-innowacje-raport-pwc.pdf $>$. 


\section{Bibliografia}

9. Spotkanie Ministrów Kultury Regionu Morza Battyckiego, „Ministerstwo Spraw Zagranicznych" [online], 23.09.2015 [dostęp: 14.10.2018], dostępny w internecie: $<$ https://www.msz. gov.pl/pl/polityka_zagraniczna/baltyk/prezydencja/9_spotkanie_ministrow_kultury_regionu_morza_baltyckiego;jsessionid=335F7F666FBA0B26573B3D39458452AE.cmsap5p $>$.

About the Programme, „Interreg Baltic Sea Region” [online], październik 2018 [dostęp: 31.10.2018], dostępny w internecie: $<$ https://www.interreg-baltic.eu/about-the-programme.html>.

Agenda 21 dla regionu Morza Battyckiego, Kraków 1999 (Bałtyk 21, 1/98) dostępny także w internecie [dostęp: 14.10.2018]: <http://ofop.eu/biblioteka/14802/agenda-21-dla-regionu-morza-baltyckiego $>$.

Baltic 2030. Renewing the commitment to sustainable development in the Baltic Sea Region, 6.06.2016, dostępny na portalu „Council of the Baltic Sea States” [online, dostęp: 14.10.2018]: <http://www.cbss.org/wp-content/uploads/2016/06/CBSS-Declaration-Baltic-2030-Warsaw-6-of-June-20161.pdf>.

Battyckie Forum Kultury, „Ministerstwo Spraw Zagranicznych” [online], 6.09.2015 [dostęp: 14.10.2018], dostępny w internecie: <http://www.mkidn.gov.pl/pages/posts/baltyckie-forum-kultury-5726.php>.

Beazley C., An EU Strategy for the Baltic sea Region. Making a success of the 2004 enlargement, „Baltic Rim Economies” 2007, issue 6.

Council of the European Union, Council conclusions on the review of the European Union Strategy for the Baltic Sea Region. 3125th General Affairs Council Meeting. Brusslels, 15 November 2011, „Komisja Europejska” [online, dostęp: 14.10.2018], dostępny w internecie: $<$ https://ec.europa.eu/regional_policy/sources/cooperate/baltic/pdf/council_conclusions_eusbsr_15112011.pdf $>$.

Czym jest strategia makroregionalna UE?, „Komisja Europejska” [online], 15.12 .2017 [dostęp: 14.10.2018], dostępny w internecie: <http://ec.europa.eu/regional_policy/pl/information/ publications/factsheets/2017/what-is-an-eu-macro-regional-strategy $>$.

Czym jest Strategia UE dla regionu Morza Bałtyckiego, „Ministerstwo Spraw Zagranicznych” [online, dostęp: 14.10.2018], dostępny w internecie: <https://msz.gov.pl/pl/polityka_zagraniczna/baltyk/strategia/czym_jest_strategia/>.

Ćwioro B., Battyk na nowe czasy-przewodnictwo Polski w Radzie Państw Morza Baltyckiego 1 lipca 2015 - 30 czerwca 2016, [w:] Battyk dla wszystkich 2016, [b.m.w. 2016].

European innovation scoreboard 2018, Luxembourg 2018, dostępny w internecie [dostęp: 14.10.2018]: <https://ec.europa.eu/docsroom/documents/33147?locale=pl >.

Europejski Ranking Innowacyjności 2018: Europa musi zwiększyć przewage $w$ dziedzinie innowacji, „Komisja Europejska” [online], 22.06.2018 [dostęp: 14.10.2018], dostępny w internecie: <http://europa.eu/rapid/press-release_IP-18-4223_en.htm>.

Exposé premier Beaty Szydło - stenogram, „Premier” [online], 15.11.2015 [dostęp: 14.10.2018], dostępne w internecie: $<$ https://www.premier.gov.pl/expose-premier-beaty-szydlo-stenogram.html>.

Fanning H., The economic development of the Baltic Sea Region - what major indicators tell us, „Baltic Rim Economies” 2017, issue 1.

Filipek M.J., Struktura organizacyjna oraz główne kierunki działalności Nordyckiej Rady Ministrów, „Zeszyty Prawnicze” (UKSW) 2009, vol. 9, nr 2. 
Frączek A., Wybrane aspekty instytucjonalizacji stosunków polsko-szwedzkich, „Studia Gdańskie. Wizje i Rzeczywistość” 2014, t. 11.

Gänzle S., The European Union's Strategy for the Baltic Sea Region (EUSBSR). Improving mutilevel governance in Baltic Sea cooperation?, komputeropis referatu wygłoszonego podczas 8 konferencji ECPR w Trydencie (15-18.06.2016), dostępny w internecie [dostęp: 14.10.2018]: $<$ https://ecpr.eu/Filestore/PaperProposal/2b170274-a0f5-4cf7-aa45-2173e65a6ffd.pdf $>$.

The global competitiveness report 2017-2018, ed. K. Schwab, Geneva 2017, dostępny w internecie [dostęp: 14.10.2018]: <http://www3.weforum.org/docs/GCR2017-2018/05FullReport/ TheGlobalCompetitivenessReport2017\%E2\%80\%932018.pdf>.

Godbold E., Strengthening the UK's military power in the Baltics, „International Centre for Defence and Security" [online], sierpień 2016 [dostęp: 14.10.2018], dostępny w internecie: $<$ https://icds.ee/strengthening-the-uks-military-power-in-the-baltics/>.

Grzybowski M., Region Morza Baltyckiego jako obszar integracji makroregionalnej w Unii Europejskiej, [w:] Perspektywy integracji gospodarczej $i$ walutowej w Unii Europejskiej w czasach kryzysu, K. Opolski, J. Górski, Warszawa 2013.

Informacja Ministra Spraw Zagranicznych nt. polityki zagranicznej RP w 2011 r., „Ministerstwo Spraw Zagranicznych" [online, dostęp: 14.10.2018], dostępna w internecie: $<$ http://msz.gov. pl/pl/polityka_zagraniczna/priorytety_polityki_zagr_2012_2016/expose2/expose2011/>. Informacja Rady Ministrów o zadaniach polskiej polityki zagranicznej w latach 2014-2015, „Ministerstwo Spraw Zagranicznych” [online], 6.11.2014 [dostęp: 14.10.2018], dostępna w internecie: <http://www.msz.gov.pl/pl/aktualnosci/wiadomosci/minister_grzegorz_ schetyna_o_priorytetach_polskiej_dyplomacji $>$.

Kierunek innowacje! Polskie firmy na ścieżce rozwoju, „PwC” [online], listopad 2017 [dostęp: 14.10.2018], dostępny w internecie: $<$ https://www.pwc.pl/pl/pdf/publikacje/kierunek-innowacje-raport-pwc.pdf $>$.

Komunikat Komisji do Parlamentu Europejskiego, Rady, Europejskiego Komitetu Ekonomiczno-Społecznego i Komitetu Regionów dotyczacy Strategii Unii Europejskiej dla Regionu Morza Battyckiego [COM (2009) 248/3], „Komisja Europejska” [online], 10.06.2009 [dostęp: 14.10.2018], dostępny w internecie: <https://ec.europa.eu/regional_policy/sources/ docoffic/official/communic/baltic/com_baltic_pl.pdf $>$.

Konferencja Parlamentarna Morza Battyckiego, „Senat Rzeczypospolitej Polskiej” [online, dostęp: 14.10.2018], dostępny w internecie: <https://www.senat.gov.pl/kontakty-miedzyparlamentarne/stale-delegacje-do-zgromadzen-miedzyparlamentarnych/konferencja-parlamentarna-morza-baltyckiego/>.

Konferencja Wspólpracy Subregionalnej Państw Morza Baltyckiego, „Instytut Morski w Gdańsku” [online], 24.09.2018 [dostęp: 14.10.2018], dostępny w internecie: <http://im.gda.pl/ aktualnosci/994-konferencja-wspopracy-subregionalnej-pastw-morza-batyckiego>.

Latvian Presidency 2018-2019, „Council of the Baltic Sea States” [online, dostęp: 14.10.2018], dostępny w internecie: <http://www.cbss.org/latvian-presidency-2018-2019/>.

Lemaitre M., EU supporting cooperation across borders in the Baltic Sea Region, „Baltic Rim Economies" 2018, $\mathrm{nr} 2$.

Łodziński S., Wspótpraca regionalna i transgraniczna $w$ regionie Morza Bałtyckiego [Informacja nr 660], „Biuro Studiów i Ekspertyz Kancelarii Sejmu” [online], 1999 [dostęp: 14.10.2018], dostępny w internecie:. <http://biurose.sejm.gov.pl/info/index.htm>.

Matera R., Integracja ekonomiczna krajów nordyckich, Torun 2001. 
Mazur-Barańska A., Wymiar Pótnocny Unii Europejskiej, „Sprawy Międzynarodowe” 2000, t. $53, \mathrm{nr} 2$.

Moraczewska A., Region Morza Baltyckiego, [w:] Regiony w stosunkach międzynarodowych, red. J. Topolski, Lublin 2009.

$N B 8$, „Ministry of Foreign Affairs of the Republic of Lithuania” [online], 25.06.2018 [dostęp: 14.10.2018], dostępny w internecie: $<$ https://www.urm.lt/default/en/foreign-policy/ lithuania-in-the-region-and-the-world/regional-cooperation/nb8 $>$.

Northern group defence ministers met in The Hague, „Government Offices of Sweden” [online], 7.06.2018 [dostęp: 14.10.2018], dostępny w internecie: <https://www.government. se/articles/2018/06/northern-group-defence-ministers-met-in-the-hague $>$.

Palmowski T., ,,Wymiar Pótnocny” Unii Europejskiej, „Stosunki Międzynarodowe” 2004, t. 29 , nr 1-2.

Petna treść exposé Witolda Waszczykowskiego, „Rzeczpospolita” [online], 29.01.2016 [dostęp: 14.10.2018], dostępny w internecie: <https://www.rp.pl/Rzad-PiS/160129236-Pelna-trescexpose-Witolda-Waszczykowskiego.html >.

Piotrowski B., Integracja Skandynawii. Od Rady Nordyckiej do wspólnoty europejskiej, Poznań 2006.

Political declaration on the Northern Dimension policy, „European Union. External Action” [online, dostęp: 14.10.2018], dostępny w internecie: <http://www.eeas.europa.eu/archives/ docs/north_dim/docs/nd_political_declaration_2006_en.pdf $>$.

Polityka morska Rzeczypospolitej Polskiej do roku 2020 (z perspektywa do 2030 roku), Warszawa 2015, [załącznik do:] Uchwała nr 33/2015 Rady Ministrów z dnia 17 marca 2015 r. w sprawie Polityki morskiej Rzeczypospolitej Polskiej do roku 2020 (z perspektywa do 2030 roku), „Ministerstwo Gospodarki Morskiej i Żeglugi Śródlądowej” [online, dostęp: 14.10.2018], dostępny w internecie: <https://mgm.gov.pl/wp-content/uploads/2016/01/ Polityka-morska-Rzeczypospolitej-Polskiej_uchw._Nr_33_RM_z_17_03_2015.pdf>.

Polska prezydencja w Radzie Państw Morza Battyckiego, „Ministerstwo Spraw Zagranicznych" [online], 1.07.2015 [dostęp: 14.10.2018], dostępny w internecie: $<$ https://www.msz. gov.pl/pl/p/paryz_fr_a_pl/aktualnosci/polska_prezydencja_w_radzie_panstwa_morza_ baltyckiego? searchTag=>.

Polsko-skandynawska wspótpraca gospodarcza. Inwestycje, wymiana handlowa i skandynawscy inwestorzy w Polsce, Warszawa 2016.

Popławski K., Cele polskiej prezydencji w Radzie Państw Morza Battyckiego, „Przegląd Bałtycki” [online], 17.01.2016 [dostęp: 14.10.2018], dostępny w internecie: <http://przegladbaltycki. $\mathrm{pl} / 2265$,cele-polskiej-prezydencji-w-radzie-panstw-morza-baltyckiego.html $>$.

Puka L., Przegląd Strategii UE dla regionu Morza Battyckiego - główne wyzwania, „Biuletyn” (PISM) 2011, nr 67 (816).

Purju A., The economies of the Baltic Sea Region. Growth patterns and foreign trade now and in the future, ,Journal of East-West Business” 2013, vol. 19 (1-2).

Raś K., Polityka Polski w regionie Morza Battyckiego, „Rocznik Polskiej Polityki Zagranicznej” 2016 [w druku].

Raś K., Polityka zagraniczna Polski wobec państw battyckich, „Rocznik Polskiej Polityki Zagranicznej" 2016 [w druku].

The role of Baltic identity and cooperation in political developments [wywiad Karoliiny Raudsepp z Andresem Kasekampem], „Baltic Times” [online], 21.04.2011 [dostęp: 14.10.2018], dostępny w internecie: <https://www.baltictimes.com/news/articles/28526/>. 
Swedish Presidency 2017-2018, „Council of the Baltic Sea States” [online, dostęp: 14.10.2018], dostępny w internecie: <http://www.cbss.org/swedish-presidency-2017-2018/>.

Śmigerska-Balczak I., Wspótpraca państw w regionie Morza Baltyckiego-Rada Państw Morza Bałtyckiego, „Kwartalnik Kolegium Ekonomiczno-Społecznego »Studia i Prace «”2012, nr 1.

Think Nordic \& Baltic. Business opportunities on your doorstep, „GOV.UK” [online], 2013 [dostęp: 14.10.2018], dostępny w internecie: <https://assets.publishing.service.gov.uk/ government/uploads/system/uploads/attachment_data/file/203627/Nordic_and_Baltics_ Business_Opportunity.pdf $>$.

Trusewicz I., Skandynawia znów bije świat na głowę, „Rzeczpospolita” [online], 25.06.2017 [dostęp: 14.10.2018], dostępny w internecie: <https://www.rp.pl/Gospodarka/306259964Skandynawia-znow-bije-swiat-na-glowe.html >.

Uchwała nr 33/2015 Rady Ministrów z dnia 17 marca 2015 r. w sprawie Polityki morskiej Rzeczypospolitej Polskiej do roku 2020 (z perspektywa do 2030 roku), „Ministerstwo Gospodarki Morskiej i Żeglugi Śródlądowej” [online, dostęp: 14.10.2018], dostępna w internecie: $<$ https://mgm.gov.pl/wp-content/uploads/2016/01/Polityka-morska-Rzeczypospolitej-Polskiej_uchw._Nr_33_RM_z_17_03_2015.pdf $>$.

Wymiar Pótnocny, „Ministerstwo Spraw Zagranicznych” [online, dostęp: 14.10.2018], dostępny w internecie: $<$ https://www.msz.gov.pl/pl/c/MOBILE/polityka_zagraniczna/baltyk/ wymiar_polnocny/>.

Zygierewicz A., Wspótpraca państw nordyckich, „Biuro Studiów i Ekspertyz Kancelarii Sejmu” [online], styczeń 2005 [dostęp: 14.10.2018], dostępny w internecie: $<$ http://biurose.sejm. gov.pl/teksty_pdf_05/i-1115.pdf>. 